\title{
A BNT162b2 mRNS-Pfizer-BioNTech- védőoltás hatásosságának és immunogenitásának monitorozása egészségügyben dolgozókon
}

\author{
Rojkovich Bernadette dr. - Németh Dóra - Török Eszter dr. \\ Szabó Bernadette dr. - Pintér Ágnes dr. - Juhász István dr. \\ Weidl Márton dr. - Lányi Éva dr. - Pável-Szecskó Judit dr. \\ Lázár Imre dr. - Perduk András dr. - Reiter József dr. \\ Nagy György dr. - Nagy Erzsébet dr. - Géher Pál dr.
}

A Betegápoló Irgalmasrend Budai Irgalmasrendi Kórháza, Budapest

\begin{abstract}
Bevezetés: A SARS-CoV-2 koronavírus okozta COVID-19 általános egészségügyi és gazdasági krízist idézett elő. Célkitüzés: A megfigyeléses vizsgálat célja a BNT162b2 mRNS-Pfizer-BioNTech-vakcina hatásosságának, biztonságosságának és immunogenitásának igazolása a Budai Irgalmasrendi Kórház dolgozóin.

Módszer: A vakcina adása után elemeztük a COVID-19-fertőzés előfordulását, az oltások utáni reakciókat, valamint a „spike” ( $\mathrm{S}$-) protein és a nukleokapszid (N)-protein elleni ellenanyag szintjének változását.

Eredmények: A felmérésben részt vevő 295 dolgozó közül az oltást megelőzően 36 dolgozó esett át COVID-19-fertőzésen (COVID-19-pozitív csoport). A második oltás után a megfigyelési időszak három hónapjában COVID-19fertőzés nem alakult ki a felmérésben részt vevő oltott dolgozók körében. Az oltási reakciók enyhék voltak. A COVID-19-pozitív csoportban az $\mathrm{N}$-antitestek medián küszöbértékindexe az első vakcina után 4 héttel mérve szignifikánsan magasabb volt $(28,37)$, mint a COVID-19-negatív $(0,085)$ csoportban $(\mathrm{p}<0,0001)$. Az első vakcina után 4 héttel az S-antitestek medián értéke $(8015 \mathrm{U} / \mathrm{ml})$ a COVID-19-pozitív csoportban szignifikánsan magasabb volt $(\mathrm{p}<0,0001)$, mint a COVID-19-negatív csoportban $(23,18 \mathrm{U} / \mathrm{ml})$. A COVID-19-negatív csoport S-antitestközépértéke a második vakcina után szignifikáns $(\mathrm{p}<0,0001)$, mintegy $500 \times$-os emelkedést mutatott $(23,18 \mathrm{U} / \mathrm{ml}$ ről $1173 \mathrm{U} / \mathrm{ml}-\mathrm{re})$. Egy vakcina hatásosságát a fertőzések terjedésének megakadályozása igazolja.

Következtetések: A második vakcina utáni megfigyelési időszakban új COVID-19-fertőzés nem volt az oltott dolgozók körében. A fertőzésen át nem esett COVID-19-negatív egyének esetén az S-antitest emelkedése mérsékelt az első oltás után, míg a második oltás után lényegesen emelkedik. A COVID-19-fertőzésen átesett egyének csoportjában már az első vakcina is jelentős $S$-antitest-termelődést vált ki.
\end{abstract}

Orv Hetil. 2021; 162(39): 1551-1557.

Kulcsszavak: ellenanyag, COVID-19, COVID-vakcina, immunitás, Pfizer-BioNTech, „spike” protein

Immunogenicity and safety of the BNT162b2 mRNA COVID-19 vaccine in healthcare workers

Introduction: The coronavirus disease 2019 (COVID-19) pandemic caused global public health and economic crises. Objective: The aim of this observation study was to estimate the effectiveness, safety and elicited immune response of the BNT162b2 mRNA Pfizer-BioNTech vaccine in healthcare workers of the Buda Hospital of the Hospitaller Order of St. John of God.

Method: After vaccination, the infection rate, adverse events and the kinetics of anti-SARS-CoV-2 spike (S) protein and anti-SARS-CoV-2 nucleocapsid $(\mathrm{N})$ protein antibodies were evaluated.

Results: Before vaccination, from the 295 healthcare workers 36 recovered from prior COVID-19 infection (COVID-19-positive group). After the second vaccination, there was no COVID-19 infection during the threemonth follow-up period. The adverse events were mild. In the COVID-19-positive group, the median cut-off index of anti-N antibodies measured at 4 weeks after the first vaccination were significantly $(\mathrm{p}<0.0001)$ higher $(28.37)$ than 
in the COVID-19-negative group (0.085). After the first vaccine, the median titer of anti-S antibodies was significantly higher $(\mathrm{p}<0.0001)$ in the COVID-19-positive group $(8015 \mathrm{U} / \mathrm{ml})$ compared to the COVID-19-negative group $(23.18 \mathrm{U} / \mathrm{ml})$. In the COVID-19-negative group, the median titer of anti-S antibodies increased significantly $(\mathrm{p}<0.0001)$ after the second vaccine (from $23.18 \mathrm{U} / \mathrm{ml}$ to $1173 \mathrm{U} / \mathrm{ml}$ ), showing an increase of $500 \times$.

Conclusions: After the second vaccination, there was no COVID-19 infection during the follow-up. In the COVID19-negative group, the anti-S antibody titer is moderate after the first vaccination and increases significantly after the second vaccine. In the COVID-19-positive group, the first vaccine induces significant anti-S antibody production.

Keywords: antibody, COVID-19, COVID vaccine, immunity, Pfizer-BioNTech, spike protein

Rojkovich B, Németh D, Török E, Szabó B, Pintér Á, Juhász I, Weidl M, Lányi É, Pável-Szecskó J, Lázár I, Perduk A, Reiter J, Nagy Gy, Nagy E, Géher P. [Immunogenicity and safety of the BNT162b2 mRNA COVID-19 vaccine in healthcare workers]. Orv Hetil. 2021; 162(39): 1551-1557.

(Beérkezett: 2021. július 27.; elfogadva: 2021. augusztus 11.)

\section{Rövidítések}

$\mathrm{CD}=($ cluster of differentiation $)$ differenciációs klaszter; COI $=($ cut-off index $)$ küszöbértékindex; COVID-19 = (coronavirus disease 2019) koronavírus-betegség 2019; ETT-TUKEB = Egészségügyi Tudományos Tanács, Tudományos és Kutatásetikai Bizottság; Ig = immunglobulin; IQR = (interquartile range) interkvartilis tartomány; MERS-CoV $=$ (Middle-East respiratory syndrome coronavirus) közel-keleti légúti koronavírus; mRNS = (messenger RNS) hírvivő RNS; $\mathrm{N}=$ nukleokapszid; $\mathrm{NK}=$ (natural killer) természetes ölősejt; $\mathrm{PCR}=($ polymerase chain reaction) polimeráz-láncreakció; $\mathrm{Q}=$ (quartile) kvartilis; $\mathrm{RBD}=$ (receptor-binding domain) receptorkötő domén; $\mathrm{RNS}=$ ribonukleinsav; $\mathrm{S}=$ (spike) tüske; SARS-CoV-2 = (severe acute respiratory syndrome coronavirus 2 ) súlyos akut légúti tünetegyüttest okozó koronavírus-2

A koronavírusok egyszálú RNS-vírusok. Az eddig ismert négy humán koronavírus általában enyhe, mérsékelt felső légúti tüneteket okozott, míg a közel-keleti légúti koronavírus (MERS-CoV) és a súlyos akut légúti tünetegyüttest okozó koronavírus (SARS-CoV) súlyos légúti megbetegedésekhez vezetett. A 2019-ben újonnan kialakult, SARS-CoV-2 okozta koronavírus-betegség (COVID-19) [1] az egész világon elterjedő pandémiát okozott, amely napjainkban komoly egészségügyi és gazdasági krízishelyzetet teremtett. Magyarországon az első COVID-19-fertőzést két, hazánkban tanuló iráni diáknál észlelték 2020. 03. 04-én [2]. 2020 végére az újabb vírusvariánsok megjelenése további kihívást jelent a fertőzés elleni védekezésben.

A fertőzés leggyakoribb tünete a láz, a száraz köhögés, a fáradékonyság, a nehézlégzés, jellemző tünete az íz- és szaglásérzés elvesztése. A betegség a leggyakrabban enyhe és közepes lefolyású $(80 \%)$, ritkább a súlyos (14\%) és a kritikus $(6 \%)$ kimenetel, 2-3\%-ban végződik halállal.

A fertőzés gyógyítására még nincs hatásos gyógymódunk, nagy erőkkel folyik a gyógyszerkutatás az antivirális szerek fejlesztésére. A fertőzés megelőzése különösen fontos. A fertőzés elkerülése érdekében a járvány egyes fázisaiban a társadalmi érintkezések számát csökkenteni kell, a távolságtartás, a maszkviselés, a gyakori kézmosás rendszabályait be kell tartani. A prevenció másik fontos eszköze a védőoltás. A védőoltások [3] bevezetésétől reméljük a pandémia feltartóztatását, a súlyos betegségkimenetel megelőzését. Az oltás hatásosságát jellemzi, hogy milyen százalékban tudja megakadályozni az oltott személy megbetegedését, az esetleges súlyos szövődmények kialakulását; ezt több más tényező is befolyásolja, mint például az életkor, a krónikus alapbetegségek, az oltás beadása óta eltelt idő, az oltást megelőző COVID19-fertőzés. Ezért az egyes vakcinák hatásosságának mértéke csak az oltást követően fellépő fertőzések, megbetegedések, kórházi felvételek és halálesetek számának alakulása alapján határozható meg.

\section{Célkitüzések}

A Betegápoló Irgalmasrend Budai Irgalmasrendi Kórházában az egészségügyi dolgozók és az egészségügyben dolgozó, de a betegellátásban részt nem vevő egyéb munkatársak első kampányvédőoltása 2021. január 7-én kezdődött el. Az oltás utáni védettség vizsgálatára a dolgozóknak az oltást követően fellépő fertőzéseit elemezzük, emellett az ellenanyagszint-változás kinetikáját vizsgáljuk.

A beavatkozással nem járó, prospektív obszervációs vizsgálatunk célja a SARS-CoV-2 ellen kifejlesztett [4] Pfizer-BioNTech-vakcina (Comirnaty) immunogenitásának és hatásosságának vizsgálata. Elsődleges végpontja az oltás utáni egy évben a fertőzés elleni védettség felmérése a klinikai tünetek észlelésével. A dolgozatban az első három hónap előzetes eredményeit ismertetjük. A másodlagos végpont a SARS-CoV-2 „spike” (S-) protein (tüskefehérje) és nukleokapszid $(\mathrm{N})$-protein elleni ellenanyag szintjének nyomon követése, emellett összehasonlítottuk a COVID-19-fertőzésen átesett (COVID19-pozitív) és a fertőzésen át nem esett (COVID-19-negatív) egészségügyi dolgozóknak a vakcináció hatására kialakuló antitestválaszát. 
A kutatási terv a hatályos hazai jogszabályok és az Orvosok Világszövetségének Helsinki Deklarációja szerint történt, az ETT-TUKEB IV-1287-1/2021/EKU engedélye alapján.

\section{Módszerek}

A Betegápoló Irgalmasrend Budai Irgalmasrendi Kórházának 18 éven felüli, 555 egészséges egészségügyi és egészségügyben dolgozó munkatársa közül 2021. január 7. és március 8. között az első kampányvédőoltás során, üzemorvosi vizsgálat keretében, 345 dolgozó kapta meg a Pfizer-BioNTech-vakcina két dózisát. A vakcina beadása előtt a dolgozókat szóban és írásban tájékoztattuk a COVID-19-fertőzés veszélyeiről, a védőoltás előnyeiról. Anamnézis és klinikai vizsgálat után kapták meg az elsó védőoltást, a másodikat három hét elteltével. A védőoltásra jelentkezés és a védőoltás utáni ellenőrzéseken való részvétel is a dolgozók önkéntes döntése volt. Ha a monitorozást nem vállalta a dolgozó, az nem befolyásolta, hogy védőoltásban részesüljön. A munkatársak között várandós vagy szoptató nő nem volt, anamnézisükben vakcina- vagy gyógyszeradás után anafilaxiás reakció nem szerepelt, az első oltás előtti három hónapban COVID19-fertőzés nem fordult elő. Az oltás előtt felmértük a COVID-19-fertőzésre hajlamosító rizikótényezőket, kísérő betegségeket, az anamnézisben COVID-19-fertőzésre utaló panaszokat, az előzetesen rendelkezésre álló, SARS-CoV-2 kimutatására szolgáló PCR-eredményeket. Felmértük az oltás utáni reakciókat, megmértük a SARSCoV-2 elleni két antitesttitert, az S-protein és az N-protein elleni ellenanyag szintjét mindkét oltás után egy hónappal ( \pm 10 nap). A második oltás után három hónap elteltével felmértük, hogy kialakult-e új COVID-19-fertőzésre utaló klinikai tünet.

A SARS-CoV-2-N-antitestek meghatározása Roche (Bázel, Svájc) Elecsys anti-SARS-CoV-2-teszttel, a SARSCoV-2-S-antitesteké Roche Elecsys anti-SARS-CoV-2-Steszttel elektrokemilumineszcenciás immunkémiai eljárással történt. Az N-antitest- (anti-SARS-CoV-2-teszt) pozitivitás küszöbértékindexe (COI; mintajel/küszöbértékjel) $\geq 1,0$. Az S-antitest- (anti-SARS-CoV-2-S-teszt) pozitivitás küszöbértéke $\geq 0,80 \mathrm{U} / \mathrm{mL}$.

Az eredmények értékelését a nonparametrikus eloszlások medián értékeinek megadásával, a csoportok összehasonlítását Mann-Whitney-módszerrel, 95\%-os konfidenciaszinttel végeztük, Minitab (State College, PA, Amerikai Egyesült Államok) statisztikai programcsomag használatával. A szignifikancia határa $\mathrm{p}<0,05$ volt. Az eredmények ábrázolására boxplot diagramot használtunk a medián, 'interquartile range' (IQR), 25-ös (Q1) és 75-ös $(\mathrm{Q} 3)$ percentilisek megadásával.

\section{Eredmények}

A Betegápoló Irgalmasrend Budai Irgalmasrendi Kórházának telephelyén 2020. március 16. és 2021. január 7.
1. táblázat |A kutatásban részt vevő dolgozók adatai, kísérő betegségei és rizikótényezői

\begin{tabular}{lrc}
\hline & $\mathrm{n}$ & $\begin{array}{c}\text { Életkor, medián } \\
(\min .-\max .)\end{array}$ \\
\hline Összes dolgozó & 295 & $50(22-81)$ \\
Férfi & 82 & \\
Nő & 213 & \\
\hline
\end{tabular}

Az oltás előtt COVID-19

COVID-19-fertőzött (n) $36 \quad 49$ (24-73)

Nem fertôzött $(\mathrm{n})$

$259 \quad 52(22-81)$

Munkakör (n)

Orvos 99

Egészségügyi dolgozó $\quad 126$

Egészségügyben dolgozó más munkatárs $\quad 65$

Gyógyszerész

5

Fennálló betegségek

Hypertonia, szív-ér rendszeri betegség 69

Diabetes mellitus

Pajzsmirigybetegség

11

Allergia

46

Krónikus gyulladásos betegség

4

Krónikus tüdőbetegség

COVID-19 = koronavírus-betegség 2019

között az 555, egészségügyi és egészségügyben dolgozó munkatárs közül ezen időszakban 120 dolgozónál (a dolgozók 21,6\%-a) igazolódott a klinikai tünetek és a PCR-pozitivitás alapján COVID-19-fertőzés. 2021. január 7. és március 8 . között 345 dolgozó kapta meg a Pfizer-BioNTech-vakcina (Comirnaty) mindkét dózisát. Az első oltás előtt felajánlott egyéves nyomon követést 40 dolgozó nem vállalta, tíz dolgozót kizártunk az értékelésből hiányzó adatok vagy a második oltás elmaradása miatt. A második oltás elmaradásának oka egy dolgozónál az elsô oltás után kialakult, mérsékelt tünetekkel járó COVID-fertőzés, két dolgozónál pedig heves oltási reakció volt, ezért ők később kapták meg a második védőoltást. A második oltást megkapó egyik dolgozónknál az oltás után igazolódott a második oltáskor még tünetmentesen zajló COVID-19-fertőzés, amely két héten belül gyógyult; nála is kifejezett oltási reakciót észleltünk. A felmérésben részt vevő 300 dolgozó közül 295 dolgozónak állt rendelkezésre mindkét ellenanyagszintmérése. A 295 dolgozó átlagéletkora 50 (22-81) év, köztük 213 nő és 82 férfi. A dolgozók demográfiai adatait, munkakörét, kísérő betegségeit, a fertőzésre hajlamosító rizikótényezőket az 1 . táblázat tartalmazza. A Pfizer-BioNTech-vakcinával végzett első és második oltás után észlelt oltási reakciók általában 24 órán belül elmúltak, és enyhék voltak, a második oltás után gyakrabban jelentkeztek; mindezt részletesen a 2. táblázatban foglaltuk össze. 
2. táblázat

Az első és a második BNTl62b2-oltás után tapasztalt oltási reakciók

\begin{tabular}{lcc}
\hline Oltási reakció & Az első oltás után & A második oltás után \\
\cline { 2 - 3 } & $(\%)$ & $(\%)$ \\
\hline Enyhe helyi fájdalom & 71 & 61 \\
Enyhe helyi bőrpír & 3 & 3 \\
Nyirokcsomó-duzzanat & 3 & 4 \\
Fáradtság & 16 & 39 \\
Fejfájás & 9 & 20 \\
Szédülés & 3 & 8 \\
Hốemelkedés & 3 & 8 \\
Borzongás & 5 & 19 \\
\hline
\end{tabular}

Az N-protein elleni ellenanyag negativitása azt jelezte, hogy a dolgozó feltehetőleg nem esett át COVID19-fertőzésen. Ezt retrospektív PCR-adatgyüjtéssel erősítettük meg. A 295 dolgozó közül 26 esetben volt előzetesen klinikai tüneteket okozó COVID-19-fertőzés, hárman a pandémia első, míg 23 dolgozónk a pandémia második hullámában esett át PCR-teszttel igazolt COVID-19-fertőzésen. Tíz dolgozónknál az N-protein elleni ellenanyag-pozitivitás valószínűsítette a tünetmentesen lezajlott fertőzést, PCR-teszt nem történt. A dolgozók COVID-19-fertőzései mérsékelt klinikai tünetekkel jártak, súlyos, kórházi ellátást indokló szövődmény nem volt. Az első védőoltás után két dolgozó kapott két héten belül gyógyuló, mérsékelt tünetekkel járó fertőzést. A második oltás után a megfigyelési időszak három hónapjában COVID-19-fertőzés nem volt a felmérésben részt vevő oltott dolgozók körében.

Az 1. ábra a COVID-19-negatív és -pozitív dolgozók $\mathrm{N}$-antitest-értékeit mutatja az első oltás után. Az N-antitestek medián COI-je az első vakcina után 4 héttel mér-

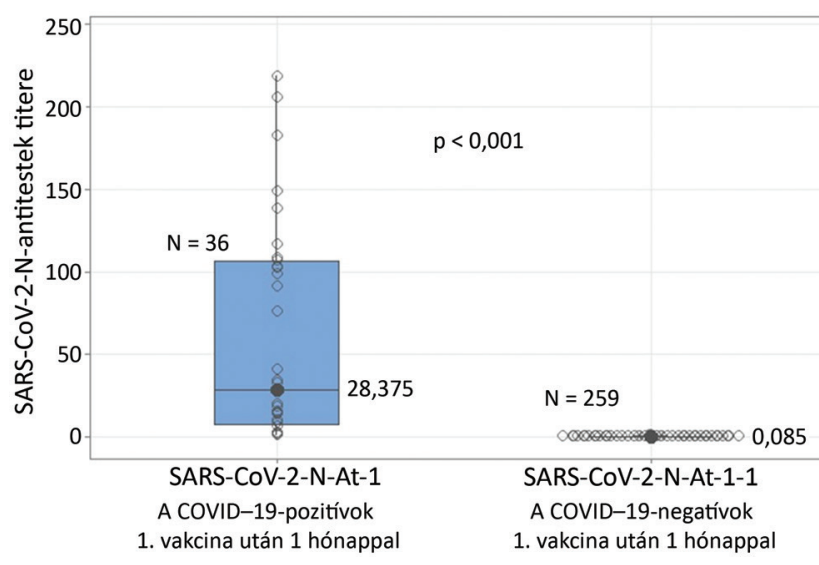

1. ábra $\quad$ A COVID-19-pozitív $(\mathrm{n}=36)$ és COVID-19-negatív $(\mathrm{n}=$ 259) személyek SARS-CoV-2-N-antitest-titere az elsố BNT162b2 vakcina után 1 hónappal

Boxplot diagramok a medián, 'interquartile range' (IQR), 25 ös (Q25) és 75-ös (Q75) percentilisek adataival

COVID-19 = koronavírus-betegség 2019; SARS-CoV-2 = súlyos akut légúti tünetegyüttest okozó koronavírus-2 ve a COVID-19-pozitív csoportban $(\mathrm{n}=36) 28,375$ (Q25: 7,13; Q75: 106,23), míg a COVID-19-negatív csoportban $(\mathrm{n}=259)$ 0,085 (Q25: 0,08; Q75: 0,091) volt; a két csoport $\mathrm{N}$-antitest-értékei szignifikáns különbséget $(\mathrm{p}<0,0001)$ mutattak (1. ábra). A COVID19-pozitív csoportnak az első (COI: 28,375) és a második (COI: 28,06) vakcina után 4 héttel mért $\mathrm{N}$-antitest-értékei nem különböztek szignifikánsan ( $\mathrm{p}=$ 0,791 ), amit a 2. ábra mutat.

A COVID-19-negatív és -pozitív dolgozók S-antitestjének medián értékei az első vakcina után 4 héttel a COVID-19-pozitív csoportban $8015 \mathrm{U} / \mathrm{ml}$ (Q25: 4309; Q75: 18020), a COVID-19-negatív csoportban 23,18 U/ml (Q25: 7,4; Q75: 7358) volt; a két csoport

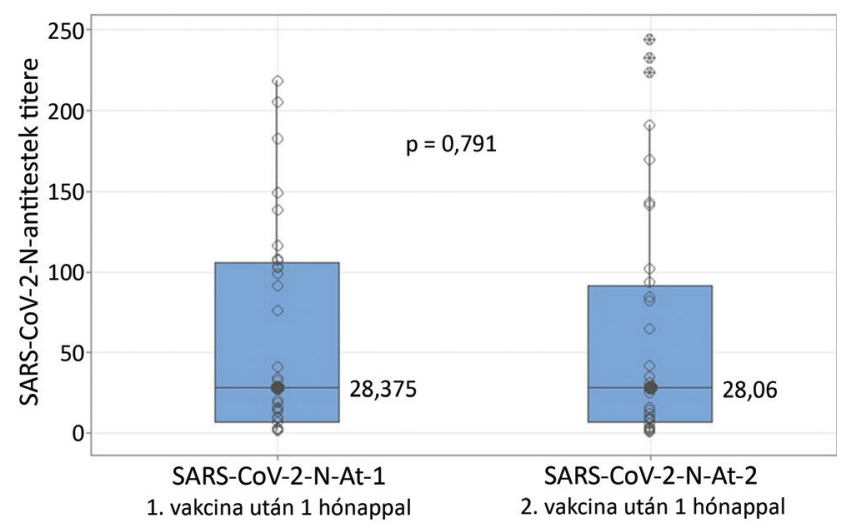

2. ábra $\quad$ A COVID-19-pozitív személyek $(\mathrm{n}=36)$ SARS-CoV-2-N-antitest-titere az első és a második BNT162b2 vakcina után 1 hónappal

Boxplot diagramok a medián, 'interquartile range' (IQR), 25-ös (Q25) és 75-ös (Q75) percentilisek adataival

COVID-19 = koronavírus-betegség 2019; SARS-CoV-2 = súlyos akut légúti tünetegyüttest okozó koronavírus-2

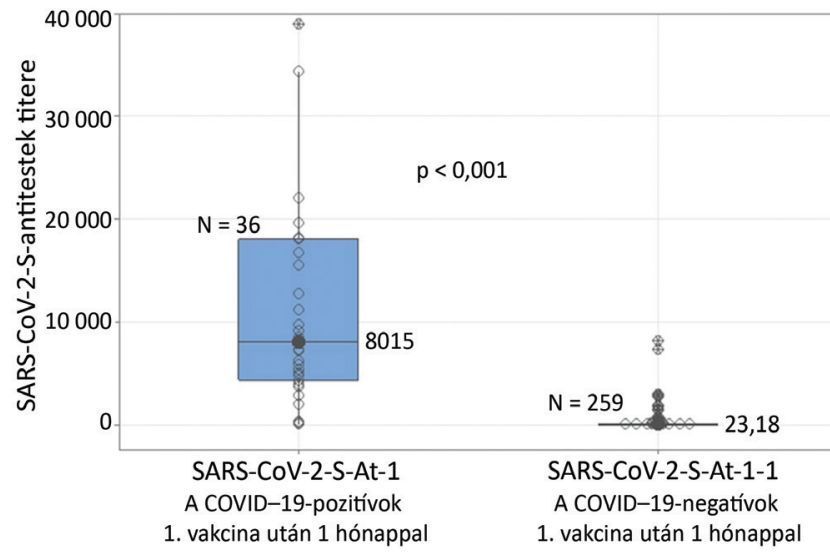

3. ábra $\quad$ A COVID-19-pozitív $(\mathrm{n}=36)$ és COVID-19-negatív $(\mathrm{n}=$ 259) személyek SARS-CoV-2-S-antitest-titere az első BNT162b2 vakcina után 1 hónappal

Boxplot diagramok a medián, 'interquartile range' (IQR), 25ös (Q25) és 75-ös (Q75) percentilisek adataival

COVID-19 = koronavírus-betegség 2019; SARS-CoV-2 = súlyos akut légúti tünetegyüttest okozó koronavírus-2 


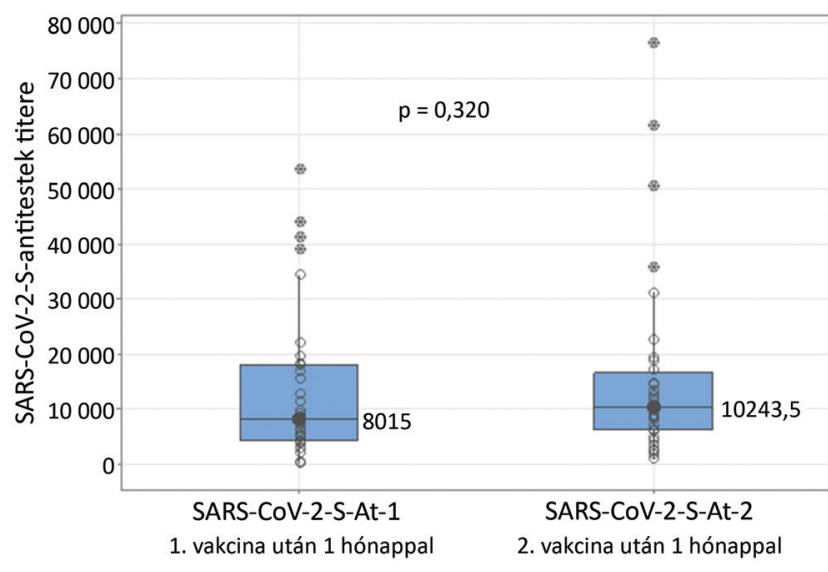

4. ábra $\quad$ A COVID-19-pozitív személyek $(\mathrm{n}=36)$ SARS-CoV-2-S-antitest-titere az első és a második BNTl62b2 vakcina után 1 hónappal

Boxplot diagramok a medián, 'interquartile range' (IQR), 25ös (Q25) és 75-ös (Q75) percentilisek adataival

COVID-19 = koronavírus-betegség 2019; SARS-CoV-2 = súlyos akut légúti tünetegyüttest okozó koronavírus-2

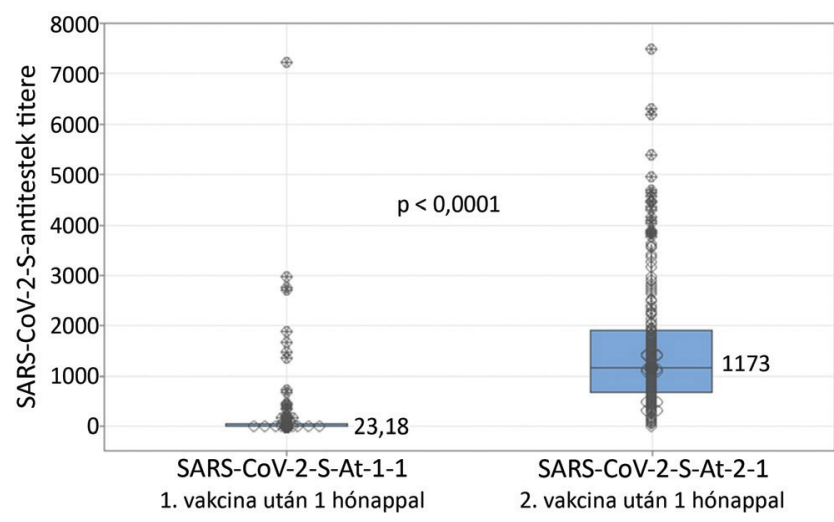

5. ábra

A COVID-19-negatív személyek $(\mathrm{n}=259)$ SARS-CoV-2-S-antitest-titere az első és a második BNTl62b2 vakcina után 1 hónappal

Boxplot diagramok a medián, 'interquartile range' (IQR), 25 ös (Q25) és 75-ös (Q75) percentilisek adataival

COVID-19 = koronavírus-betegség 2019; SARS-CoV-2 = sú lyos akut légúti tünetegyüttest okozó koronavírus-2

S-antitest-értékei szignifikáns $(\mathrm{p}<0,0001)$ különbséget mutattak (3. ábra). A COVID-19-pozitív csoportban az S-antitest középértékei az első (8015 U/ml; Q25: 4309; Q75: 13711) és a második (10 $243 \mathrm{U} / \mathrm{ml}$; Q25: 6156,75; Q75: 16 503,3) oltás után (4. ábra) nem emelkedtek szignifikánsan $(\mathrm{p}=0,320)$. A COVID19-negatív csoport S-antitest-középértéke az első vakcina után 23,18 U/ml (Q25: 7,4; Q75: 73,58), míg a második vakcina után $1173 \mathrm{U} / \mathrm{ml}$ (Q25: 691,6; Q75: 1917 ) volt, ami szignifikáns ( $\mathrm{p}<0,0001)$, mintegy $500 \times$ os emelkedést mutatott (5. ábra).

Két dolgozónál tapasztaltuk, hogy a második oltás után egy hónappal sem emelkedett jelentősen a két anti- testtiter. Egyik dolgozónk krónikus ízületi gyulladás miatt metotrexátterápiát kapott, másik dolgozónknál kíséró betegséget nem találtunk, immunszupprimációt okozó gyógyszert nem szedett.

\section{Megbeszélés}

A SARS-CoV-2 RNS-ét körülvevő strukturális fehérjék váltják ki a szervezet immunválaszát. A vírus-S-glikoprotein a megfertőzött sejt receptorához kötődik, két alegységből áll: az S1-alegység a receptorkötő helyével (RBD) a sejtfelszíni receptorhoz kötődik, a $\$ 2$-alegység a fúziós fehérje sejtbe jutását segíti elő. Az $\mathrm{N}$-protein a vírusnukleinsavat fedi, szerepe van a vírusreplikációban $[5,6]$.

A SARS-CoV-2-fertőzés és a védőoltás humorális és sejtes immunválaszt [7] vált ki. Fertőzés után a humorális immunválaszra jellemző az IgM-, majd a 12. nap után az IgG-ellenanyagok megjelenése. A specifikus antitestek a vírus-N- vagy S-protein S1- és S2-alegysége ellen termelődnek. A fertőzés után a vírus-N-ellenanyag-szint emelkedik meg, míg az S-protein S1-alegysége ellen immunizáló védőoltások az $S$-ellenanyag-szint emelkedését váltják ki. Az S-protein és az N-protein elleni ellenanyag szintjét különböző szerológiai módszerrel határozzák meg; több szerológiai teszt csak IgG- és IgM-ellenanyagot mér, ezért a különböző módszerekkel mért eredményeket nehéz összevetni. Vizsgálatunkban a SARS-CoV2-S1- és -N-ellenanyag kvantitatív mérését a 97,6\%-os szenzitivitást és 99,8\%-os specificitást mutató Roche diagnosztikus módszerrel [8] végeztük, mely a totális IgGés IgM-szintet méri. A sejtes immunválaszra [9] jellemző a CD4+, CD8+ T-lymphocytasejtszám, a B-lymphocyta-, NK-sejtszám csökkenése, ami összefüggést mutat a betegség súlyosságával. A memória B-és T-sejtek hosszú távon védelmet nyújthatnak a fertőzés ellen. Kutatásunk során a sejtes immunválaszt nem vizsgáltuk.

Egészségeseken végzett nyílt, dóziskereső, I. fázisú vizsgálatban Anderson és mtsai az mRNA-1273 vakcinát jól tolerálhatónak találták. A nagyobb esetszámú további vizsgálatok $[10,11]$ és saját tapasztalataink alapján az oltási reakciók enyhék, és az oltás hatásos védelmet nyújt a COVID-19-fertőzés ellen. Az irodalmi adatok alapján a fertőzést megakadályozó protektív antitesttiter szintje jelenleg még nem ismert, ezért a védőoltás hatásosságának bizonyítására az új fertőzések száma a jellemzőbb paraméter. A Pfizer-BioNTech-vakcina (Comirnaty) első dózisa után az S-protein-ellenanyag szintjének emelkedése már valószínúleg bizonyos fokú védettséget jelent, de a második oltás után az ellenanyagszint-emelkedés jelentósebb [12-14].

Subbarao és mtsai [15] 185, Londonban élö, 70 évnél idősebb lakos immunválaszát vizsgálták a Pfizer-BioNtech-vakcina első dózisa után. A Roche S-antitest-vizsgálat már az első oltás után 3 héttel mérsékelt pozitivitást mutatott, a második oltás után az antitesttiter jelentősen emelkedett. Az I-III. fázisú klinikai vizsgálatokba a súlyos kísérő betegségben szenvedő betegeket nem vonták 
be, ezért a betegek oltásával kapcsolatban kevesebb a tapasztalat. A májtranszplantált [16] és a hemodialízis [17] alatt álló, immunszuppresszív gyógyszereket szedő, krónikus betegeknek az oltásra adott humorális immunválasza gyengébb [18]. COVID-19-vakcináció után alacsonyabb antitesttitert találtak Watanabe és mtsai [19] centrális obesitas, hypertonia, dohányzás esetén; ezekben az esetekben a COVID-19-fertőzés előfordulása és súlyossága is gyakoribb, ami összefügghet az alacsonyabb antitesttiterrel. Világszerte több százmillió PfizerBioNTech-vakcinát adtak be, saját felmérésünkben közel 300 kórházi dolgozó adatait dolgoztuk fel.

Az egészségügyi dolgozók a fertőzött betegek ápolása vagy a kórházi munkájuk során jobban ki vannak téve a COVID-19-fertőzés lehetőségének; a kórházi dolgozók fertőzöttségének magasabb arányát igazolta saját felmérésünk is. A pandémia kezdete és a kórházunkban a Pfizer-BioNTech-vakcinával elkezdett oltási program (2021. január 7.) között Magyarországon 353276 esetben igazolták a COVID-19-fertőzést [2], ami a lakosság 3,65\%-át jelenti. A Betegápoló Irgalmasrend Budai Irgalmasrendi Kórházának telephelyén 555 kórházi dolgozó közül ezen időszakban 120 dolgozónál (21,6\%) igazolódott COVID-19-fertőzés a klinikai tünetek és a PCR-pozitivitás alapján.

Kórházunkban az egészségügyi dolgozók és a kórházi személyzet között súlyos, kórházi kezelést indokló COVID-19-fertőzés nem fordult elő. A védőoltás után enyhe oltási reakciók léptek fel, ritka oltási szövődményeket nem tapasztaltunk. Izraeli szerzők [20] 6710 egészségügyi dolgozó Pfizer-BioNTech-vakcinációja után a klinikai tünettel és a tünetmentesen előforduló COVID-19-fertőzések számát szignifikánsan alacsonyabbnak találták a nem oltott dolgozókénál. Az angliai SIREN multicentrikus prospektív kohorszvizsgálatban [21] az oltást megelőző COVID-19-fertőzésnek és a vakcinációnak az újabb fertőzést megelőző hatásosságát vizsgálták. A nyomon követés időtartama a második oltás utáni két hónap volt. Az első oltás utáni 21 napban a hatásosság $70 \%$, míg a második oltás utáni 7 napban $85 \%$ volt. Az első oltást megelőző COVID-19-fertőzés az oltás hatásosságát 90\%-ra emelte.

Kutatásunk korlátai között kiemeljük, hogy az egy centrumban oltott dolgozók esetszáma kevés, vizsgálati csoportunkba csak az elsóként jelentkező 300 dolgozót vontuk be. Több dolgozó a COVID-19-fertőzés miatt később kapta meg a védőoltást, ők a vizsgálatban nem vesznek részt, ezért náluk ellenanyagszint-mérés nem történt. A prospektív vizsgálat az első oltás után egy hónappal kezdődött, ezért az N- és S-protein-ellenanyag szintjének mérését az első oltás előtt nem végeztük el. A pandémia kezdetétől az első oltás beadásáig terjedő időszakot retrospektív módon mértük fel a dolgozók anamnézise, az üzemorvosi adatok és a kórházi informatikai rendszer adatbázisa alapján. A COVID-19-fertőzés igazolására PCR- és antigénteszt csak azoknál a dolgozóknál áll rendelkezésre, akiknél a fertőzés tünetei je- lentkeztek, így a tünetmentes fertőzött eseteket PCRteszttel nem tudtuk megerósíteni. Nem vizsgáltuk a CD4 és a CD8 T-sejt- és a memóriasejt-populációt.

\section{Következtetés}

A napi rutin klinikai gyakorlatban bevezetésre került a humorális immunválasz mérése, de ez az egy adat még nem ad megfelelő választ a védőoltás hatásosságának igazolására. A védőoltás hatásosságát a fertőzés terjedésének megakadályozásával tudjuk jellemezni. A védőoltás előtti pandémiás időszakban a fertőzésnek jobban kitett kórházi dolgozók között a COVID-19-fertőzés előfordulása gyakoribb volt $(21,6 \%)$, mint a lakosság körében. A második oltás után a megfigyelési időszak három hónapjában COVID-19-fertőzés nem volt a felmérésben részt vevő oltott dolgozók között, ami a védőoltás hatásossága mellett szól. A fertőzésen át nem esett, COVID19-negatív egyének esetén az S-antitest emelkedése az első oltás után szignifikánsan alacsonyabb volt, mint a fertőzésen átesett dolgozók esetében, de így is $23 \times$ meghaladta a határértéket, míg a második vakcina után mintegy 500×-os emelkedést mutatott. A COVID-19-fertőzésen átesett egyének csoportjában már az első vakcina is jelentős $S$-antitest-termelődést vált ki.

Anyagi támogatás: A laboratóriumi vizsgálatok költségeit a kórház saját kutatási forrásból finanszírozta.

Szerzői munkamegosztás: R. B.: A kézirat elkészítése. N. D.: Adatfeldolgozás. T. E., Sz. B.: Laboratóriumi vizsgálat. P. Á., J. I., W. M., L. É., P.-Sz. J.: Oltás, klinikai vizsgálatok. L. I.: Üzemorvosi klinikai vizsgálatok. P. A.: Retrospektív PCR-vizsgálatok feldolgozása. R. J.: A vizsgálat szervezése. N. Gy., G. P.: A protokoll tervezése, az adatok értékelése, a jelentés összeállítása. N. E.: Laboratóriumi vizsgálatok, a statisztikai adatok feldolgozása, a jelentés összeállítása. A szerzők elektronikus úton nyilatkoztak, hogy a cikk végleges változatát elolvasták és jóváhagyták.

Érdekeltségek: A szerzőknek nincsenek érdekeltségeik.

\section{Köszönetnyilvánítás}

Köszönetet mondunk $d r$. Karácsony Attila, $d r$. Kemecsey Balázs, dr. Lóránt Gergö, dr. Herbert Zita, dr. Koppányi Luca, dr. Juhász-Nagy Gréta oltásban való közremúködéséért és Czveiberné Duró Ilona, Makay Ildikó, Zachar Magdolna, Vas Mónika, Eperjesné Kovács Judit asszisztenseknek a vérvételek elvégzéséért.

\section{Irodalom}

[1] Hu B, Guo H, Zhou P, et al. Characteristics of SARS-CoV-2 and COVID-19. Nat Rev Microbiol. 2021; 19: 141-154.

[2] Coronamonitor. [Koronamonitor.] Available from: https://atlo. team/koronamonitor/ [accessed: August 14, 2021]. [Hungarian] 
[3] Polack FP, Thomas SJ, Kitchin N, et al. Safety and efficacy of the BNT162b2 mRNA COVID-19 vaccine. N Engl J Med. 2020; 383: 2603-2615.

[4] Karikó K. In vitro-transcribed mRNA therapeutics: out of the shadows and into the spotlight. Mol Ther. 2019; 27: 691-692.

[5] Prompetchara E, Ketloy C, Palaga T. Immune responses in COVID-19 and potential vaccines: lessons learned from SARS and MERS epidemic. Asian Pac J Allergy Immunol. 2020; 38: $1-9$.

[6] Merad M, Martin JC. Pathological inflammation in patients with COVID-19: a key role for monocytes and macrophages. Nat Rev Immunol. 2020; 20: 355-362. [Erratum: Nat Rev Immunol. 2020; 20: 448.]

[7] Walsh EE, Frenck RW Jr, Falsey AR, et al. Safety and immunogenicity of two RNA-based COVID-19 vaccine candidates. N Engl J Med. 2020; 383: 2439-2450.

[8] Schaffner A, Risch L, Aeschbacher S, et al. Characterization of a pan-immunoglobulin assay quantifying antibodies directed against the receptor binding domain of the SARS-CoV-2 S1subunit of the spike protein: a population-based study. J Clin Med. 2020; 9: 3989 .

[9] Sahin U, Muik A, Derhovanessian E, et al. COVID-19 vaccine BNT162bl elicits human antibody and $\mathrm{T}(\mathrm{H}) 1 \mathrm{~T}$ cell responses. Nature 2020; 586(7830): 594-599. [Erratum: Nature 2021; 590(7844): E17.]

[10] Mulligan MJ, Lyke KE, Kitchin N, et al. Phase I/II study of COVID-19 RNA vaccine BNT162bl in adults. Nature 2020; 586(7830): 589-593. [Erratum: Nature 2021; 590(7844): E26.]

[11] Anderson EJ, Rouphael NG, Widge AT, et al. Safety and immunogenicity of SARS-CoV-2 mRNA-1273 vaccine in older adults. N Engl J Med. 2020; 383: 2427-2438.

[12] Shrotri M, Navaratnam AM, Nguyen V, et al. Spike-antibody waning after second dose of BNT162b2 or ChAdOxl. Lancet 2021; 398: 385-387.

[13] Dagan N, Barda N, Kepten E, et al. BNTl62b2 mRNA COVID-19 vaccine in a nationwide mass vaccination setting. $\mathrm{N}$ Engl J Med. 2021; 384: 1412-1423.
[14] Brainard J, Rushton S, Winters T, et al. Introduction to and spread of COVID-19-like illness in care homes in Norfolk, UK. J Public Health (Oxf). 2021; 43: 228-235.

[15] Subbarao S, Warrener LA, Hoschler K, et al. Robust antibody responses in 70-80-year-olds 3 weeks after the first or second doses of Pfizer/BioNTech COVID-19 vaccine, United Kingdom, January to February 2021. Euro Surveill. 2021; 26: 2100329.

[16] Rabinowich L, Grupper A, Baruch R, et al. Low immunogenicity to SARS-CoV-2 vaccination among liver transplant recipients. J Hepatol. 2021; 75: 435-438.

[17] Jahn M, Korth J, Dorsch O, et al. Humoral response to SARS CoV-2-vaccination with BNT162b2 (Pfizer-BioNTech) in patients on hemodialysis. Vaccines (Basel) 2021; 9: 360.

[18] Simon D, Tascilar K, Fagni F, et al. SARS-CoV-2 vaccination responses in untreated, conventionally treated and anticytokinetreated patients with immune-mediated inflammatory diseases. Ann Rheum Dis. 2021 May 6. Doi: 10.1136/annrheumdis-2021-220461. [Epub ahead of print]

[19] Watanabe M, Balena A, Tuccinardi D, et al. Central obesity, smoking habit, and hypertension are associated with lower antibody titres in response to COVID-19 mRNA vaccine. Diabetes Metab Res Rev. 2021; e3465. Doi: 10.1002/dmrr.3465. [Epub ahead of print]

[20] Angel Y, Spitzer A, Henig O, et al. Association between vaccination with BNT162b2 and incidence of symptomatic and asymptomatic SARS-CoV-2 infections among health care workers. JAMA $2021 ; 325:$ 2457-2465.

[21] Hall VJ, Foulkes S, Saei A, et al. COVID-19 vaccine coverage in health-care workers in England and effectiveness of BNT162b2 mRNA vaccine against infection (SIREN): a prospective, multicentre, cohort study. Lancet 2021; 397: 1725-1735.

(Rojkovich Bernadett dr., Budapest, Árpád fejedelem útja 7., 1023 e-mail: rojkovich.b@irgalmas.hu)

\section{"Opprime, dum nova sunt subiti mala semina morbi." (Irtsd gyorsan ki, miből vészes kór nőhet, a csírát.)}

\footnotetext{
A cikk a Creative Commons Attribution 4.0 International License (https://creativecommons.org/licenses/by-nc/4.0/) feltételei szerint publikált Open Access közlemény, melynek szellemében a cikk bármilyen médiumban szabadon felhasználható, megosztható és újraközölhető, feltéve, hogy az eredeti szerző és a közlés helye, illetve a CC License linkje és az esetlegesen végrehajtott módositások feltüntetésre kerülnek.
} 